\title{
An Assessment of the Level, Trend, and Distribution of Multidimensional Poverty in Iran
}

\author{
Yadollah Dadgar ${ }^{1}$ \\ Mohammad Noferesti ${ }^{2}$ \\ Mohammadali Mokhtari ${ }^{3}$
}

\author{
y_dadgar@sbu.ac.ir \\ m_noferesti@sbu.ac.ir \\ mokhtm@usi.ch
}

\begin{abstract}
An accurate, and time-based poverty measurement is crucial in future policymaking as well as assessing the impact of welfare policies implemented on poverty. This study has used Multidimensional Poverty Index to calculate the various dimensions of poverty as well as the trend of changes in this index for the whole country and to compare its trend from 2006 to 2018 in all provinces of Iran in both urban and rural areas. These insights provide more accurate images of the location and dimensions of poverty, and they help to illuminate the path for future research on the causes of poverty, and also to design and target the supportive policies more effectively. The results of this paper show that multidimensional poverty in rural and suburban areas is higher than the urban areas, yet it shows slightly decreasing poverty trend. The policy message of this study necessitates a major focus on poverty alleviation in rural and suburban areas.
\end{abstract}

Keywords: Capability Poverty, Multidimensional Poverty, Poverty Trend in Iran, Rural Poverty, Provincial Poverty, Poverty Reduction Policy.

JEL Classification: P36, I32, H41.

1. Professor, Faculty of Economics, Shahid Beheshti University, Tehran, Iran.

2. Associate Professor, Faculty of Economics, Shahid Beheshti University, Tehran, Iran.

3. Ph. D. Student and Researcher in Economics, Shahid Beheshti University, Terhan, Iran and USI (Corresponding Author). 


\section{يك ارزيابى از سطح، روند، و توزيع فقر تِندبُعدى

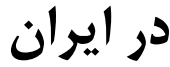

y_dadgar@sbu.ac.ir |

m_noferesti@sbu.ac.ir

mokhtm@usi.ch
يدالله دادَّر

استاد دانشكدهاقتصاد دانشكاه شهيد بهشتى.

محمد نوفرستى

دانشيار دانشكده اقتصاد دانشكاه شهيد بهشتى.

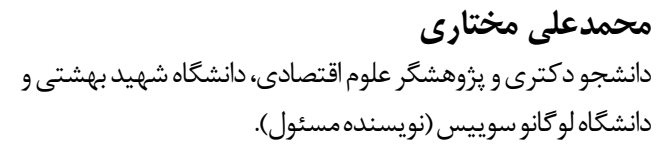

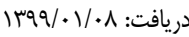
جكيده: اندازمكيرى دقيق و بهنكام فقر، اهميت بسيارى در سياستخذارى رفاهى و همجنين،

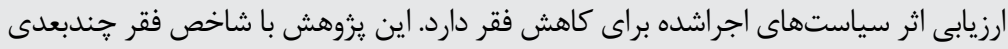

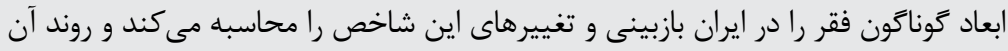

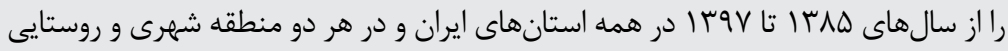

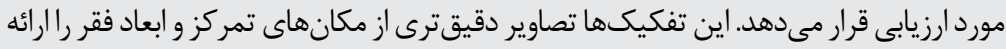

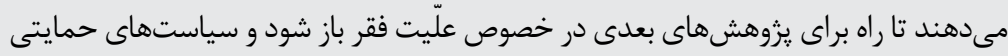

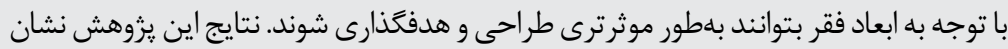

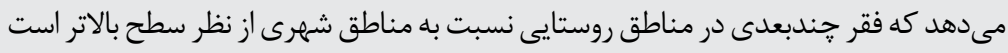

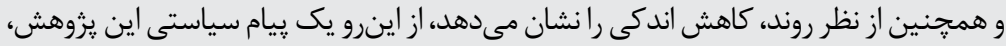
توجه اساسى به فقرزدايى در مناطق روستايى است.

كليدوازهها: فقر قابليتى، فقر جندبعدى، روند فقر در ايران، فقر روستايى، فقر استانها، سياستخذارى كاهش فقر طبقهبندى H41, I32, P36 :JEL. 


\section{مقلفمه}

اندازهيرى دقيق و بهموقع فقر از دو منظر داراى اهميت بسيار است، يكى آن است كه

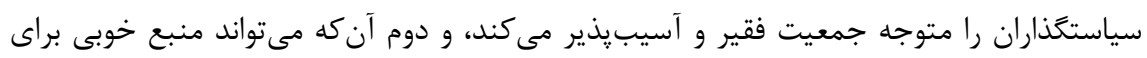

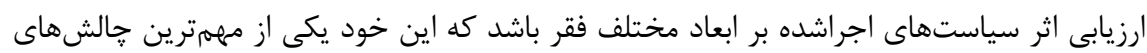

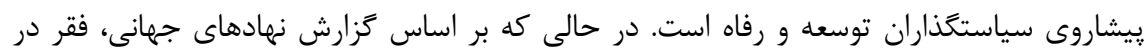

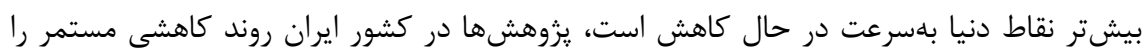

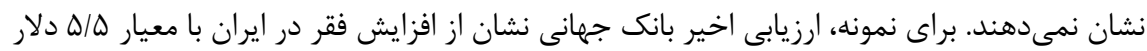
در روز دارد (World Bank, 2020)'. علاوه بر اين، توزيع جغرافيايى فقر، تصاوير دقيقترى از موقعيت بـاني

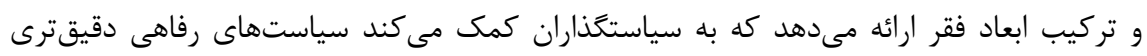

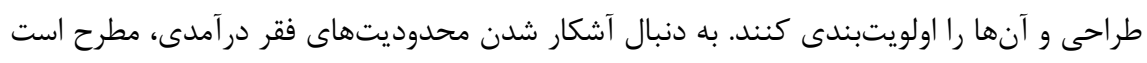

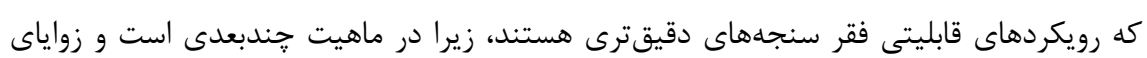

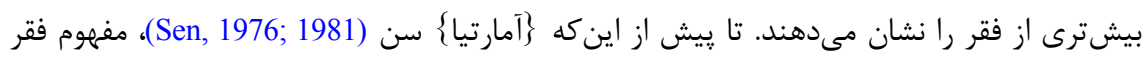

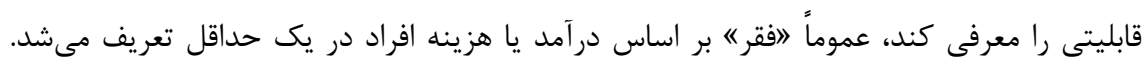

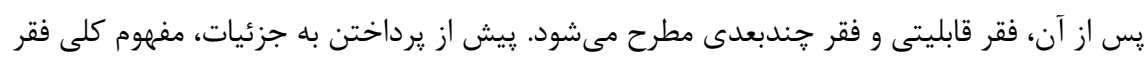

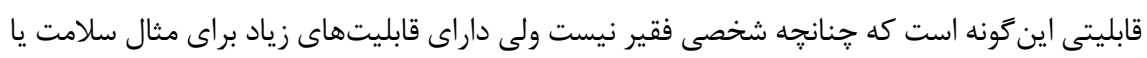

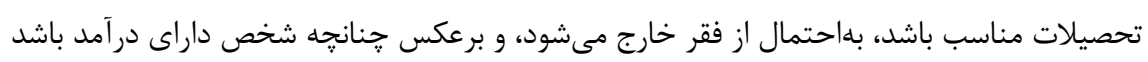

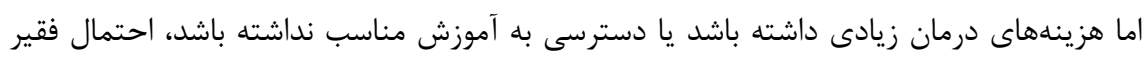

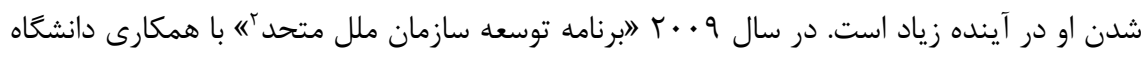

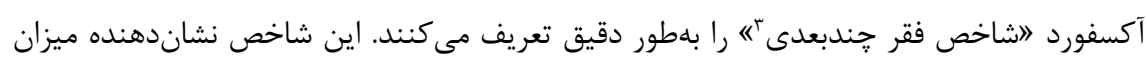

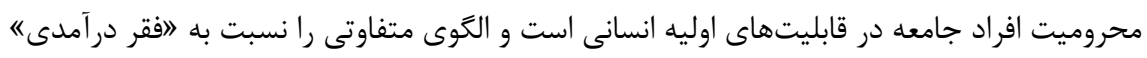

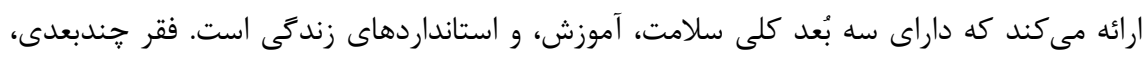

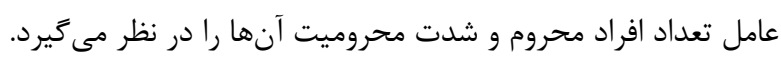

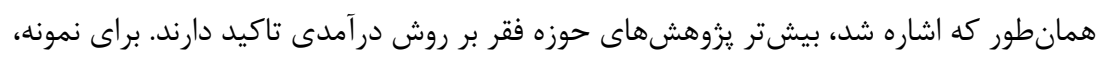

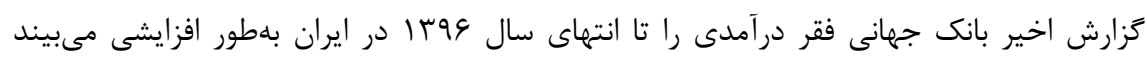

1. https://documents.worldbank.org/en/publication/documents-reports/documentdetail/ 229771594197827717/pdf

2. http://hdr.undp.org/en/2020-MPI

3. Multidimensional Poverty Index 
(World Bank, 2020) (از اينرو، بررسى بلهروز اين شاخص با معيار دقيقتر اهميت سياستخذارى

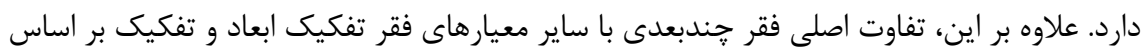

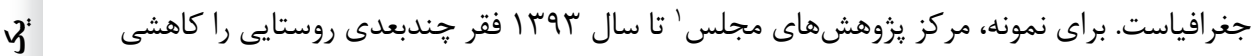

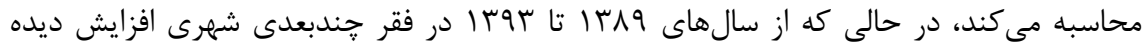
مىشود، ولى در يزوهش يادشده تفكيك منطقهاى صورت نخرفته است. نظر به اجراى سياستهاى

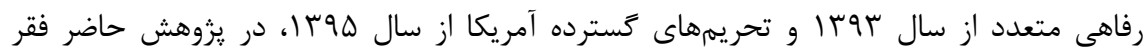

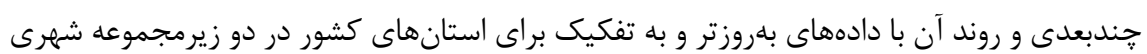
و روستايى محاسبه مىشود. زيرشاخصهاى فقر جندبعدى معرفى مىشود. سرانجام، نتايج براى شهر، روستا، و استان محاسبه و ئرسي

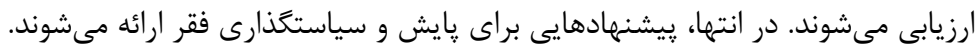

جرا فقر קندبعدى در دنيا مطرح شد و اهميت پيدا كرد؟ به باور \}آمارتيا\{ سِن، هدف نهايى

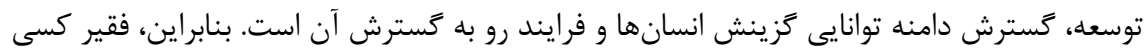

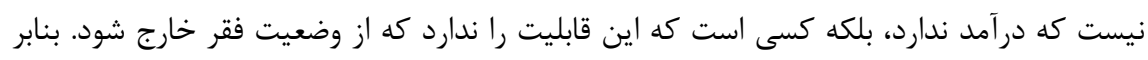

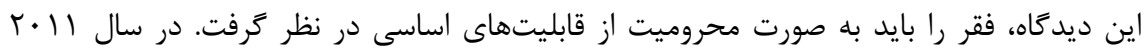

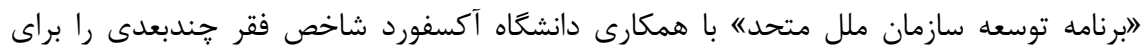

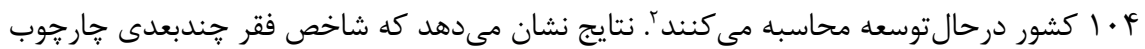

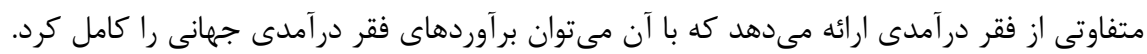

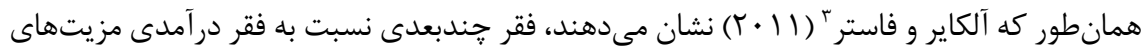

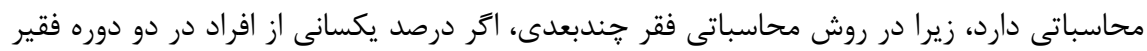
باشند، ولى يك نفر ميزان فقرش افزايش يابد، فقر جندبعدى افزايش مىيابد. همجنين، اگر يكى از

\section{1. https://rc.majlis.ir/fa/report/show/1039870}


افراد فقير شرايط بهترى يیدا كند، باز هم مستقل از اين كه شخص از فقر خارج شود يا نه، ميزان فقر جندبعدى كاهش مى يابد. كاهش ميزان فقر جندبعدى به دليل كاهش سرشمار و شدت فقر يكى از مهممترين نقاط قوت اين شاخص است و انخيزههاى دولتمردان را براى كاهش تعداد افراد فقير و تعداد

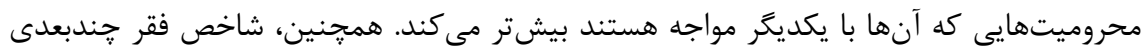

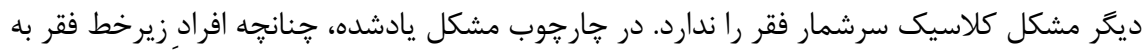
هزينه فقيران اندكى به بالا حركت كنند، نرخ سرشمار فقر بهتر مىشود. اين مشكل بزركى بر سر راه راه محاسبه فقر بود، زيرا مواردى وجود داشت كه برخلاف كاهش فقر محاسباتى، وضعيت نارضايتى در بر برد كشورها رو به افزايش بود. يزوهشها نشان مى دهند، در شرايطى كه بسيارى از شاخصهاى كلى كلان اقتصادى از جمله فقر

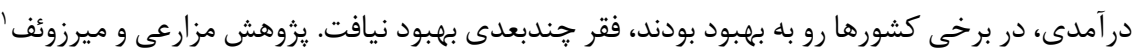

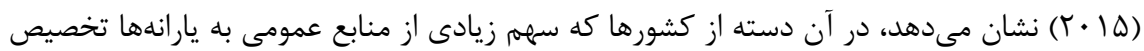

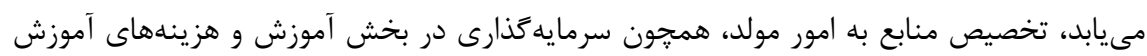

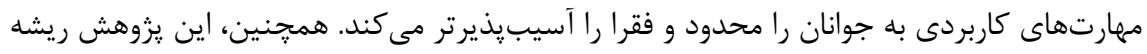

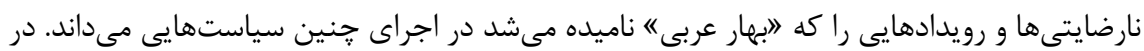
اغلب اين كشورها بخش عمومى بزرى و ناكارامد است، ولى دولت نتوانسته خدمات كافى بـ به مردم

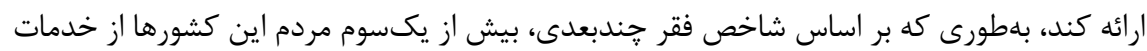

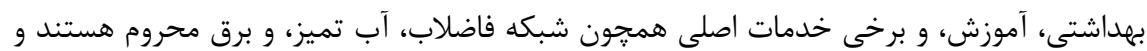

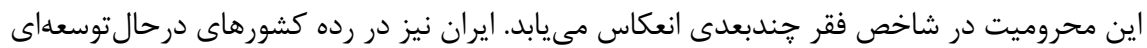

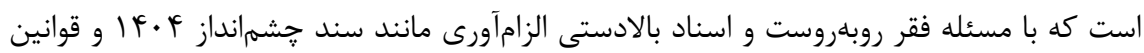

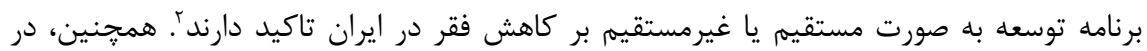
سال هاى اخير سياستهاى مسكن مهر، يرداخت يارانهها، و طرح تحول سلامت با هدف بهبود وضعيت

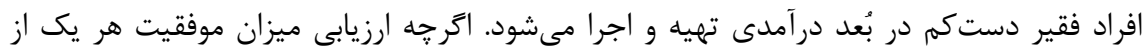

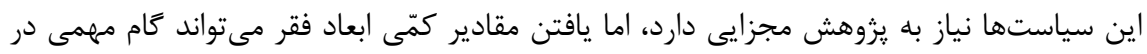

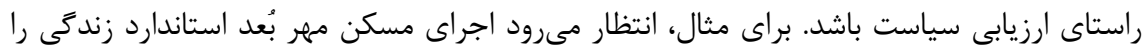

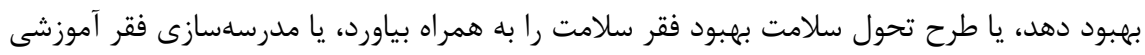

\section{Mazarei \& Mirzoev}

2. https://mpogl.ir/tosee//var/files/gavanini $\% 20$ mogararat/matne $\% 20$ sanad $\% 20$ cheshm $\% 20$ andaz.pdf 
را كاهش دهد. براى پاسخ به اين پرسشها نياز است ابعاد فقر به عنوان خروجى يك سياستكذارى به صورت استانى و به تفكيك شهر و روستا در دسترس باشد. به عنوان نمونههاى ارزيابى سياستهاى

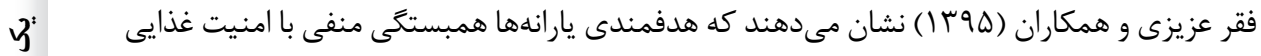

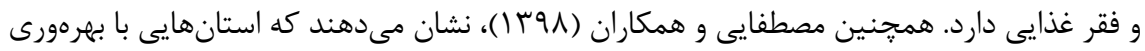

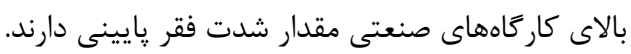

بهطور كلى، رويكردهاى متفاوت در مورد فقر را مىتوان به دو بخش رفاهگرايى و غير رفاه

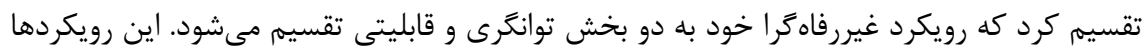
هم از نظر سنجش رفاه متفاوت هستند و هم نتيجههاى متفاوتى را در اندازه فقر بيان مى كنيند (دادكر

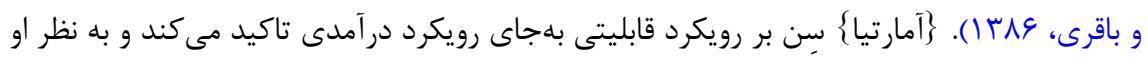

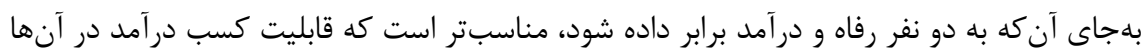

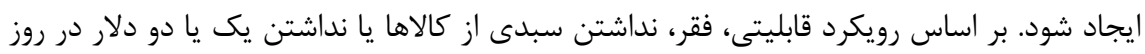

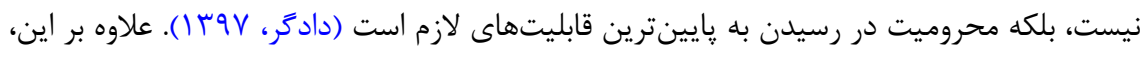

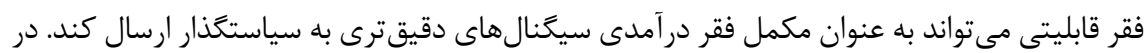
حالى كه رويكردهاى سنتى بر يك خط فقر در آمدى تكيه دارند، رويكرد قابليتى ظرفيت و توانمندى

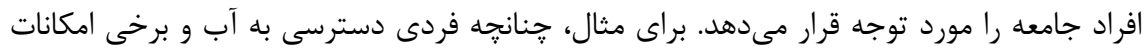

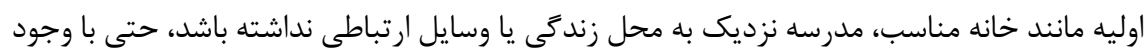

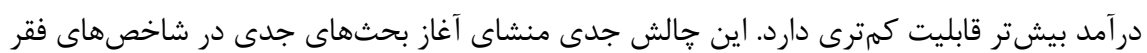
از دهd هشتاد ميلادى است. تلاش بينالمللى و فراگيرى براى فقرزدايى با ارائه گزارش توسعه انسانى سازمان ملل در سال

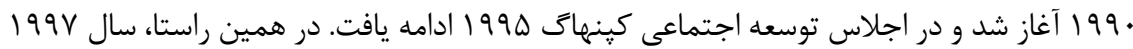

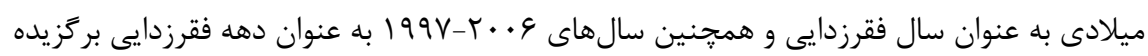

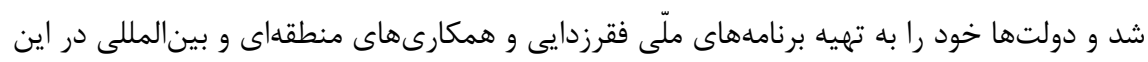

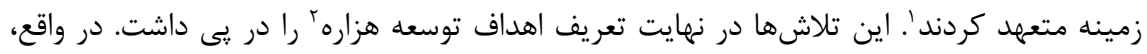

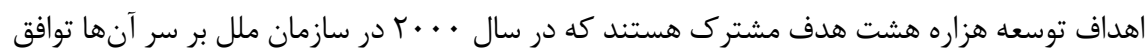
شد. نكاهى به اهداف توسعه هزاره نشان مى دهد كه شاخص فقر در آمدى بلتنهايى منعكس كننده اين 
اهداف نيست. بر اساس گزارش بانك جهانى ها • r، شاخص فقر درآمدى در كشورهاى درحالتوسعه به سا درصد كاهش يافته كه بيش از اهداف توسعه هزاره بود. در حالى كه برخى ديگر از اهداف در

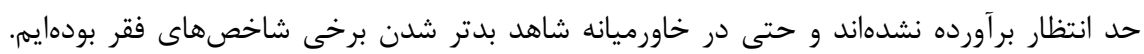

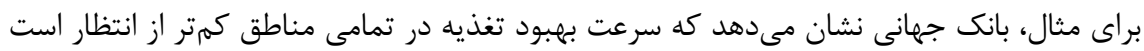

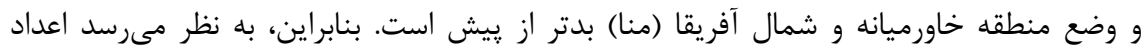

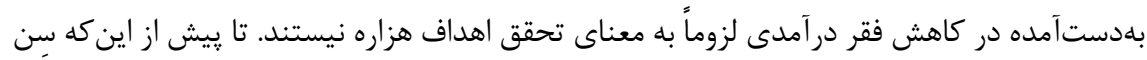

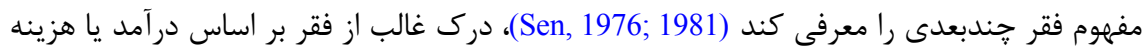

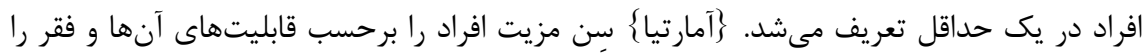
به عنوان محروميت از قابليتهاى اساسى تعريف مى كند. او با اين رويكرد فقر را با قابليتها پييوند مى دهد. اين روش داراى مزيتهاى فراوانى است، زيرا روش درآهدى محاسبة فقر كه در آن آن درآمد

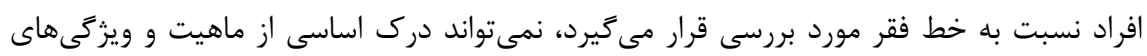

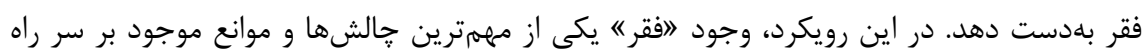

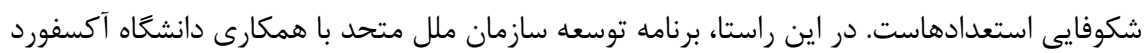

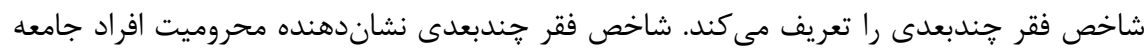
در قابليتهاى اوليه انسانى است كه الكو و تعريف متفاوتى نسبت به فقر درآمدى ارائه مى دهدد كهد

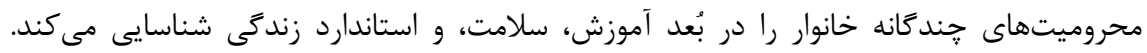

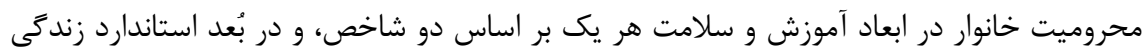
بر پايه شش شاخص محاسبه مىشود. شاخصها بر اساس نمرههاى اختصاص دادهشده به محروميت

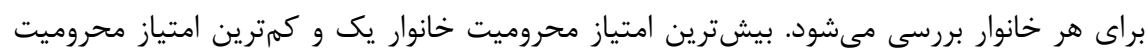

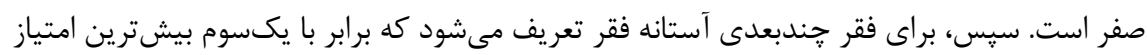

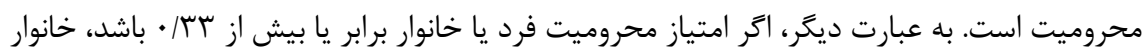

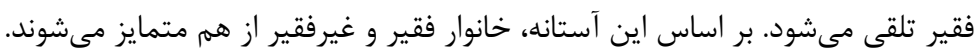
بيشتر يزوهشهاى انجامشده در مورد فقر در ايران شامل زيبايى و شوشتريان (ع^با()،

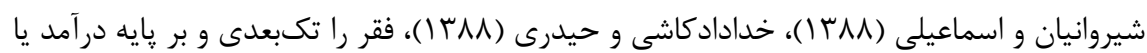

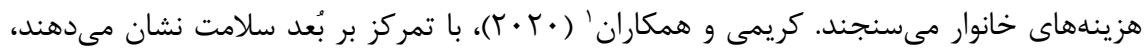

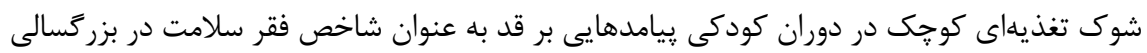


دارد. با وجود اين، بررسىهاى كمترى در زمينه فقر جندبعدى انجام پذيرفته است. براى مثال

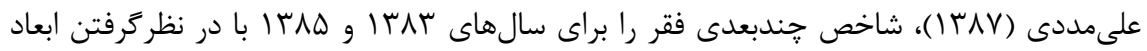
درآمد، مسكن، تملك دارايىهاى بادوام، سلامت، تامين اجتماعى، اوقات فراغت، و آموزش محاسبه

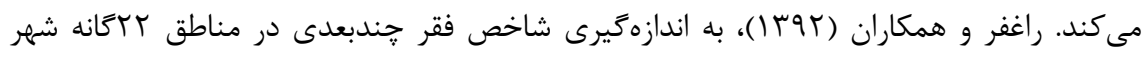

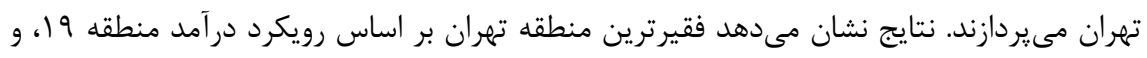

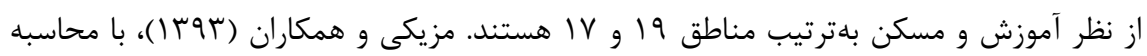
جداكانه فقر در بخشهاى سلامت، حملونقل، آموزش، و مسكن نقشهاى براى هر يكى ترسيم مى كنيند و نشان مى دهند در بيشتر شاخصها فقر مناطق مختلف كشور و جامعه روستايى و شهرى شكاف دهن

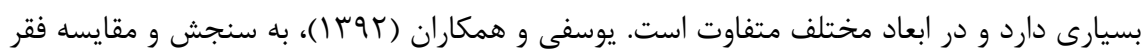

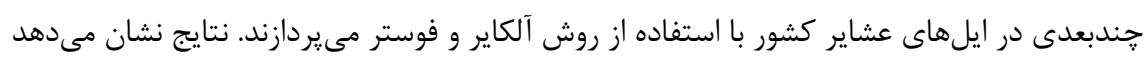

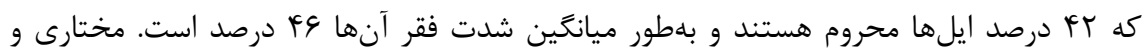

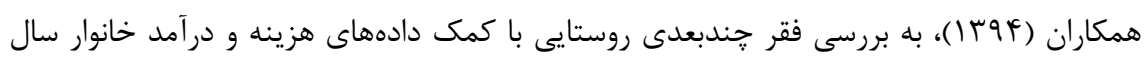

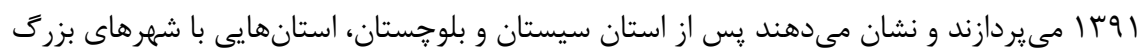

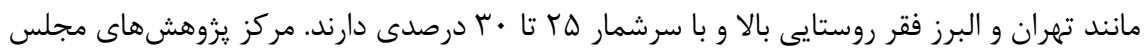

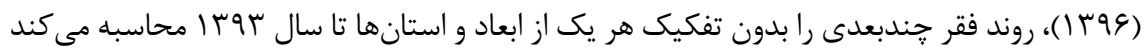

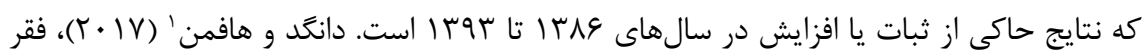

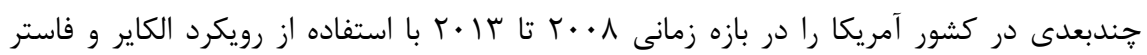

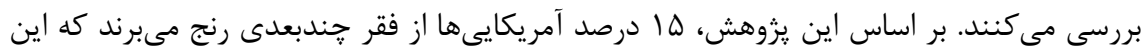
ميزان بالاتر از نرخ فقر درآمدى در اين كشور است. كم بودن تحصيلات، مشكلات محل سكونت، و و

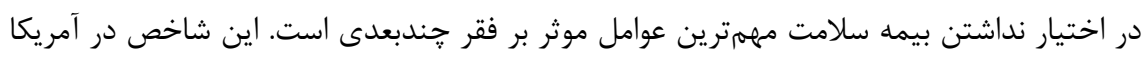

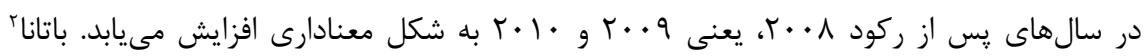

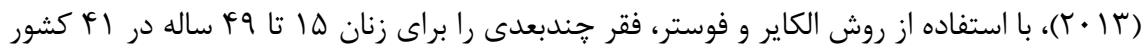

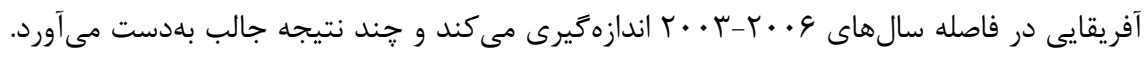
اول اينكه تفاوت كشورها در فقر جندبعدى در صحراى آفريقا مورد توجه است. دوم اينكه، فقدي

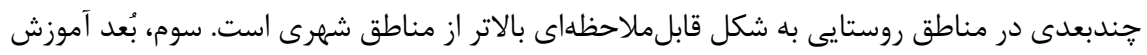


عامل اصلى تشكيلدهنده فقر جندبعدى در صحراى آفريقا براى گروه زنان ها تا وq سال است.

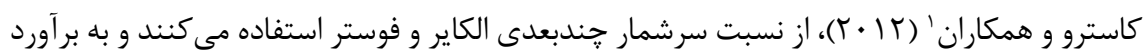

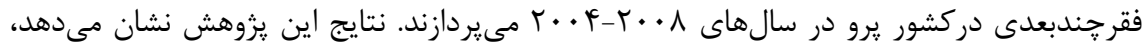
استفاده از شاخص فقر در آمدى خطاى زيادى ايجاد مى كند، به اين نحو كه افرادى ممكن است فقير محسوب نشوند، ولى به دليل شرايط نامساعد مانند آب و بهداشت در آستانه فقر قرار گَيرند. همجنين،

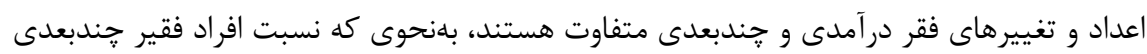

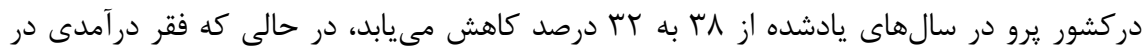

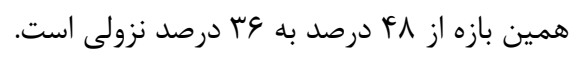

\section{روش رشناسى يخوهش}

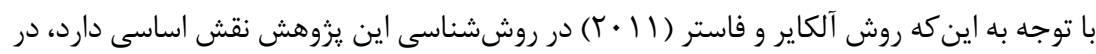

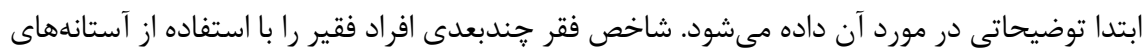
محروميت و فقر شناسايى مى كند كه شامل سه بُعد سلامت، آموزش، و استاندارد زندكَى است و هورد هر بُعد شامل جُند معيار است. جزئيات آن بر اساس آخرين استاندارد برنامه توسعه سازمان ملل در جدول

جدول ا: ابعاد فقر، جزئيات شاخصهاى مرتبط، هدف هزاره، و وزن مربوطه

\begin{tabular}{|c|c|c|c|c|}
\hline 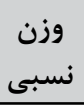 & مرتبط با آرمان & محروميت اتر ... & شاخص & ابعاد - اد \\
\hline 1/9 & آرمان r & 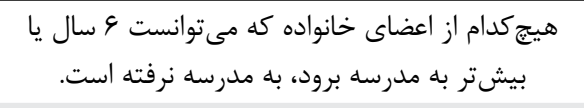 & تعداد سالهاى & \multirow{2}{*}{$\frac{1}{3}$} \\
\hline 1/9 & آرمان r & دست كم يكى از فرزندان 1 تا لها ساله به مدرسه & حضور فرزند در & \\
\hline 1/9 & آرمان F & كودكى در خانوار فوت كند. & كردومير & 3 \\
\hline 1/9 & آرمان 1 & بزركسال يا كودكى كه بايد ميزان مشخصى مواد مغذى كندي & تغذيه & \\
\hline
\end{tabular}

1. Castro et al. 
ادامه جدول ا: ابعاد فقر، جزئيات شاخصهاى مرتبط، هدف هزاره، و وزن مربوطه

\begin{tabular}{|c|c|c|c|c|}
\hline 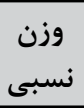 & مرتبط با آرمان & 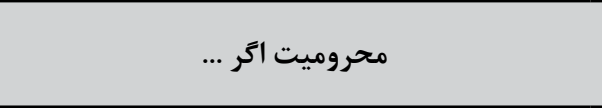 & شاخص & ابعاد \\
\hline $1 / 11$ & آرمان V V & خانوار برق ندارد. & برق & \\
\hline $1 / 11$ & 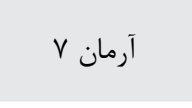 & 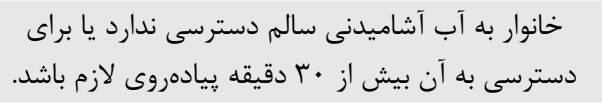 & 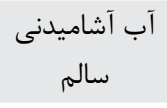 & \\
\hline $1 / 11$ & 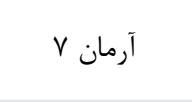 & خانوارى سرويس بهداشتى نداشته باشد يا بين جند & سيستهم تخليه & $\frac{3}{3}$ \\
\hline $1 / 11$ & 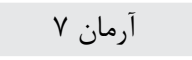 & كفيوش محل سكونت خانوار خاك، شن، و ماسه است. & كفيوش & $y$ \\
\hline $1 / 11$ & 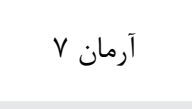 & سوخت براى پختن غذاى خانوار خوب يا زغال است. & 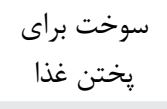 & îे \\
\hline $1 / 11$ & 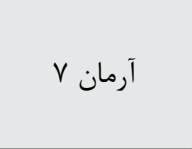 & 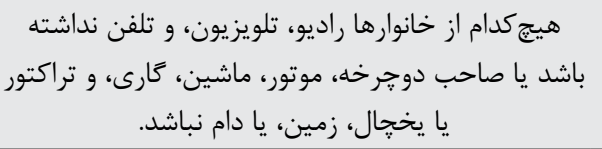 & مالكيت دارايى & \\
\hline
\end{tabular}

همانطور كه در جدول ( ) مشاهده مىشود، براى توليد شاخص فقر خندبعدى از ده شاخص با

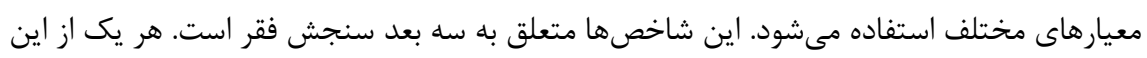

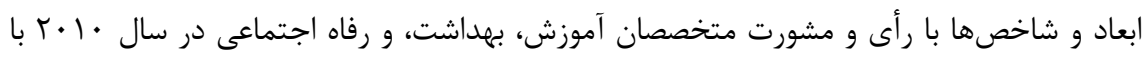

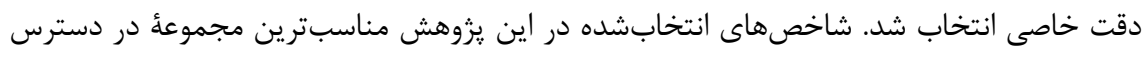

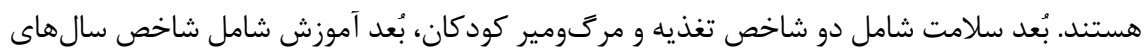

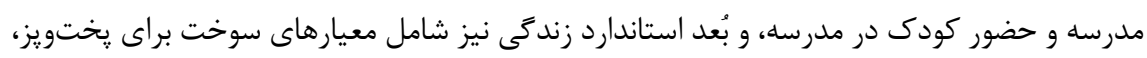

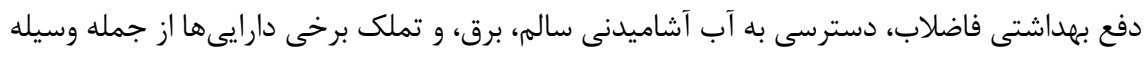

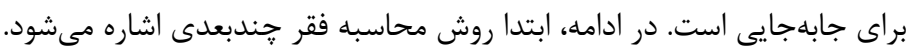

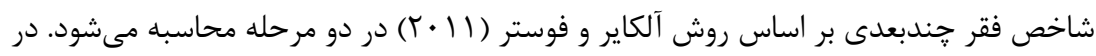

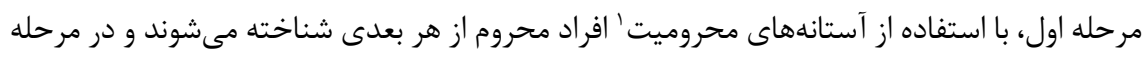

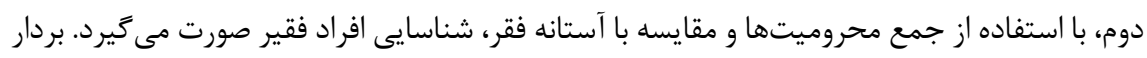

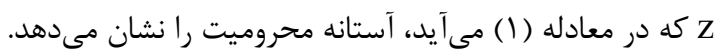
$z=\left(z_{1}, z_{2} \ldots z_{d}\right) \in \mathbb{R}_{++}^{d}$ 
كه

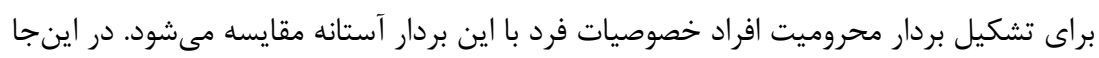

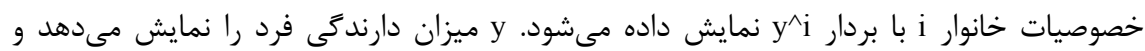
جنانجه فردى در يك بعد از آستانهاش در z كمتر باشد، محروم است: $y^{i}=\left(y_{1}^{i}, y_{2}^{i}, \ldots, y_{d}^{i}\right) \in \mathbb{R}_{+}^{d}$

بر اساس اين، بردار محروميت افراد D عبارت است از:

$D^{i}=\left(\mathrm{I}\left(y_{1}^{i} \leq \mathrm{z}_{1}\right), \ldots, \mathrm{I}\left(y_{d}^{i} \leq \mathrm{z}_{\mathrm{d}}\right)\right) \in[\cdot,]^{d}$

$I(y): Y \rightarrow\{\cdot, 1\}$

كه در آن I(0) تابع مشخصه است. يعنى در صورت درست بودن ضابطه ورودىاش، مقدار يك و در غير اين صورت مقدار صفر را برمى

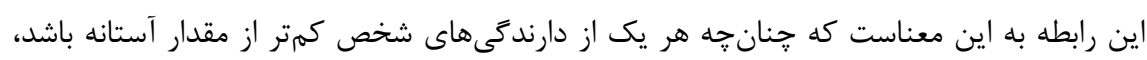

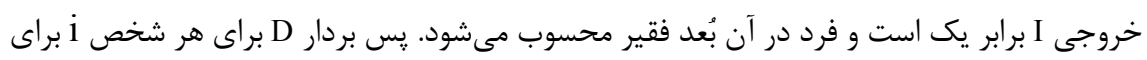

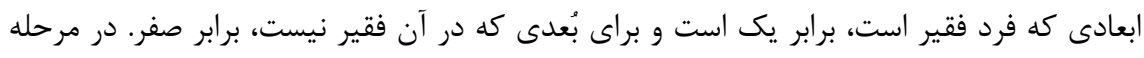

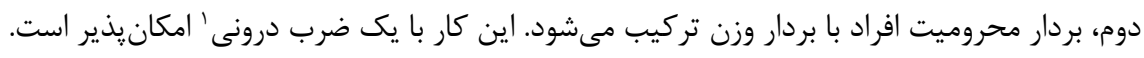
بردار وزن W نشاندهنده اهميت نسبى هر يك از معيارها است: $w=\left(w_{1}, w_{2}, \ldots, w_{d}\right) \in(\cdot, 1)^{d}$

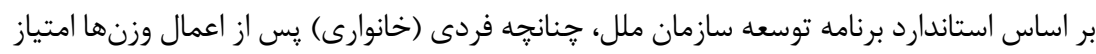

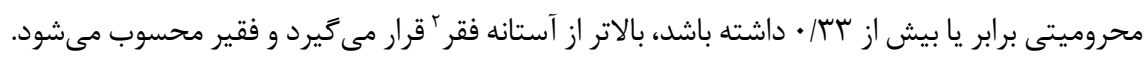

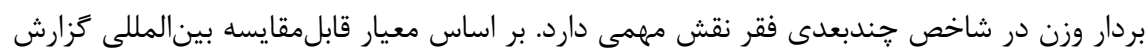

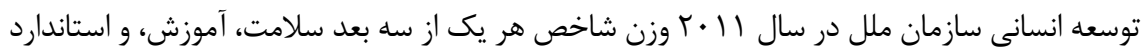

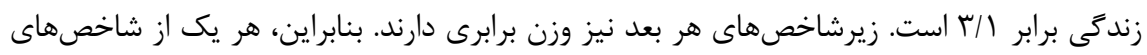

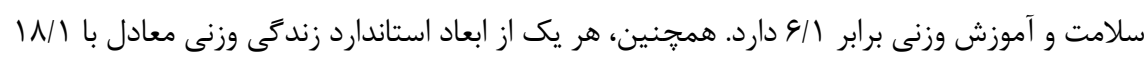
دارد. در صورتى كه در محاسبه شاخص فقر جندبعدى از ابعاد كمترى استفاده شود، وزنها بـنسيت

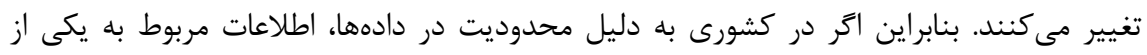

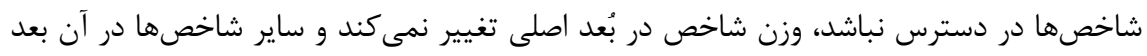


وزن بيشترى مى گيرند. در ادامه سعى مى كنيم روش محاسبه را به صورت فرم تابعى ارائه كنيم. تابع

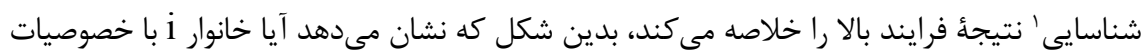

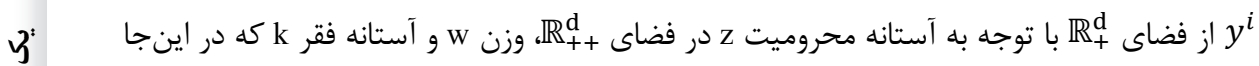

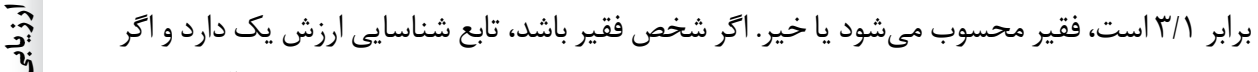

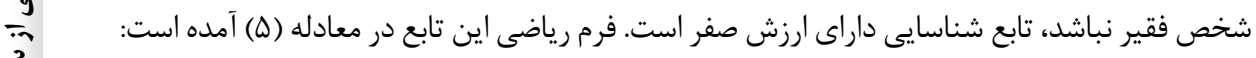
党 $\rho: \mathbb{R}_{+}^{\mathrm{d}} \times \mathbb{R}_{++}^{\mathrm{d}} \rightarrow\{\cdot, 1\}$ در واقع، م يك تابع مشخصه است كه فرم آن به شكل رابطه (ع) است و مشخص كننده اين است

$\rho\left(y^{i} \cdot \mathrm{z}\right)=\mathrm{I}\left(D \cdot \mathrm{w} \geq \frac{1}{3}\right)$ كه فرد فقير تجندبعدى محسوب مىشود يا خير: حال نياز داريم نسبت افراد فقير را محاسبه كنيم. بر اساس اين، سرشمار فقر (H) بر اساس رابطه $H=\frac{\sum_{i=1}^{N} \rho\left(y^{i} \cdot \mathrm{z}\right)}{N}$ خواهد بود: (V) كه در آن N تعداد خانوارهاست. همجنين، شدت فقر A اين گونه تعريف مىشود: $A=\frac{\sum_{i=1}^{N} I\left(\rho\left(y^{i} \cdot \mathrm{z}\right)=1\right) \times(\mathrm{D} \cdot \mathrm{w})}{\sum_{i=1}^{N} I\left(\rho\left(y^{i} \cdot \mathrm{z}\right)=1\right)}$

كه برابر ميزان محروميت يك فقير در بين ساير فقراست. در نهايت، شاخص فقر جندبعدى (MPI) عبارت است از: $M P I=H \times A$

در جنين ساختارى براى تجزيه عوامل موثر بر فقر به ابعاد آن مىتوان از تجزيه A استفاده كرد.

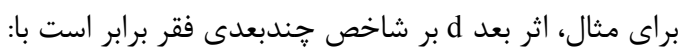
$M P I_{d}=H \times \frac{\sum_{i=1}^{I} I\left(\rho\left(y^{i} \cdot \mathrm{z}\right)=1\right) \times\left(\mathrm{I}\left(y_{d}^{i} \leq \mathrm{z}_{\mathrm{d}}\right) \times w_{d}\right)}{\sum_{i=1}^{I} I\left(\rho\left(y^{i} \cdot \mathrm{z}\right)=1\right)}$ كه در نتيجه خواهيم داشت:

$$
M P I=M P I_{1}+\cdots+M P I_{d}
$$

در ادامه، بر اساس اين معادلهها سعى در برآورد اين شاخصها براى ايران داريم. 


\section{دادهاى در دسترس ايران}

براى محاسبه شاخص جندبعدى فقر لازم است تمام دادهها از يك يزوهش بهدست آمده باشد.

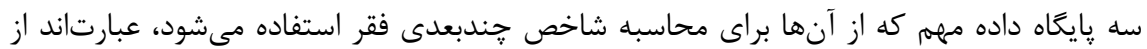

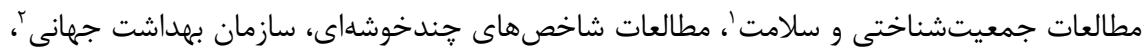
و مطالعات موردى كشورها. آرمانى اين است كه براى همه كشورها از دادهايى با يك ساختار استفاده

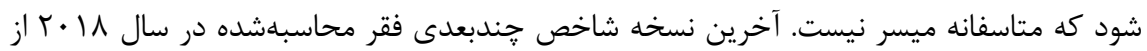
مطالعات جمعيتشناختى و سلامت (DHS)، براى محاسبه شاخص جندبعدى فقر اه كشور استفاده مى كند. براى بأ كشور از مطالعات شاخصهاى جندخوشهاى (MICS)، براى دو كشور از تركيب اين

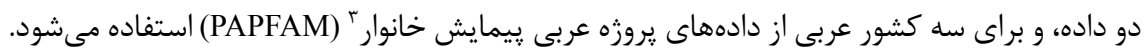

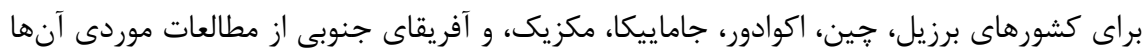
كه توسط سازمانهاى معتبر انجام مى گيرد، بهرهبردارى مىشود (Alkire \& Jahan, 2018). در صورت موتى وجود دسترسى به دادههاى قابلاطمينان، از جايخزين مناسب استفاده مىشود. علاوه بر اين، در تعريف برخى از شاخصها اختلافنظرهايى وجود دارد، يا ممكن است برخى كشورها فاقد دادهن دادهايى شامل تمام جزئيات باشند و محاسبه اين شاخص موقعيت هر كشور در ردهبندى بينالمللى را بهطور دقيق مشخص نكند. خوشبختانه دادههاى يرسشنامه طرح آماركيرى هزينه و در آمد خانوارهاى شهرى مهرى

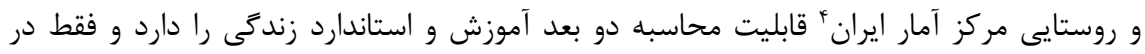

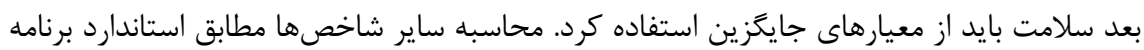

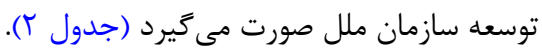

1. The Demographic and Health Surveys (DHS): https://dhsprogram.com/data/

2. Multiple Indicators Cluster Survey: https://www.unicef.org/statistics/index 24302.html

3. Pan Arab Project for Family Health: http://ghdx.healthdata.org/organizations/pan-arabproject-family-health-papfam

4. https://www.amar.org.ir/ 
جدول ז: شاخصهاى استاندارد و جايكزين براى ايران

\begin{tabular}{|c|c|}
\hline شاخص جايگزين با توجه به دادههاى ايران & شاخص استاندارد سازمان ملل \\
\hline 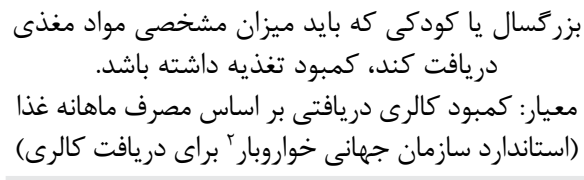 & 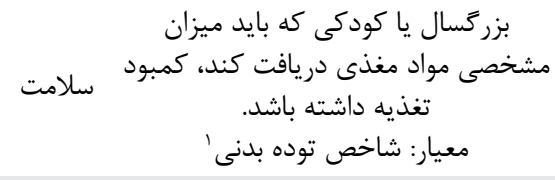 \\
\hline يوشش هر َّونه بيمهاى & كودكى در خانوار فوت كند \\
\hline معيار: خانه از جوب يا خشت زند و زل نباشد & معيار: كفيوش محل سكونت خانوار خاك، زاستاندارد \\
\hline \multicolumn{2}{|c|}{ 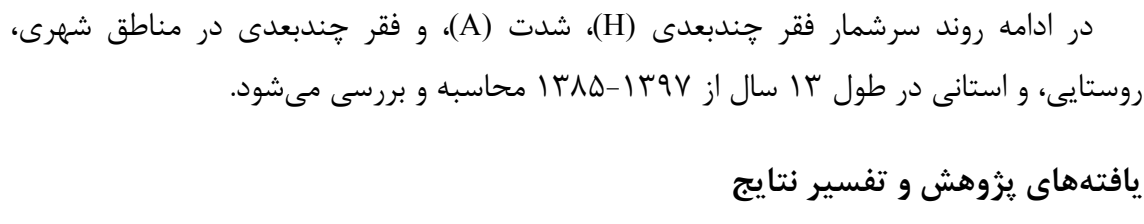 } \\
\hline
\end{tabular}

$\frac{2}{3}$
$\frac{3}{3}$
$\frac{2}{0}$
2
2
3
3
-3

سرشمار فقر جندبعدى (H))، جامعه شهرى و روستايى: اين شاخص به بيان سادهتر همان درصد افرادى هستند كه فقير جندبعدى محسوب مىشوند، يا مهمترين معيار براى قضاوت درباره

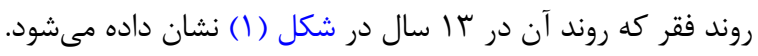

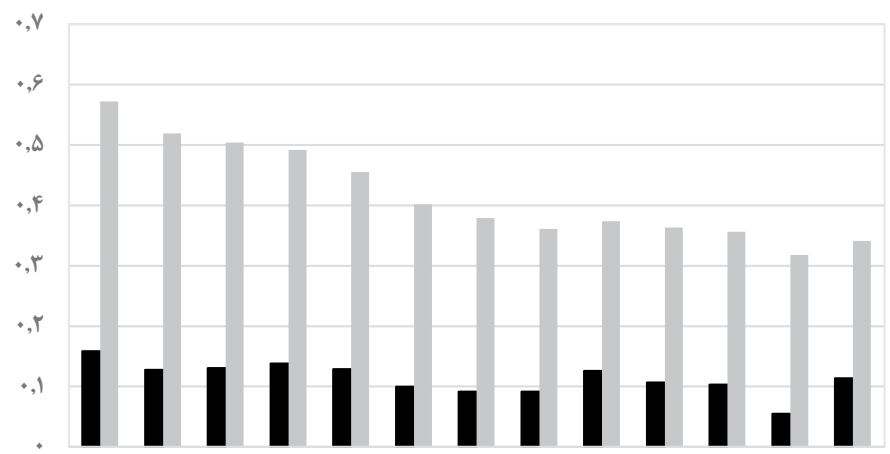

سر شمار فقر شهرى سر شمار فقر روستايى

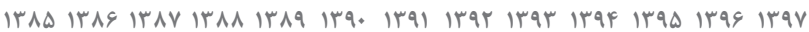

شكل ا: روند سرشمار فقر جندبعدى براى جامعه شهرى و روستايى 


\section{تحليل نتايج سرشمار فقر}

ا. با توجه به محاسبهها، همانطور كه در شكل (1) ديده مىشود، در دهه • • بـا روند نزولى

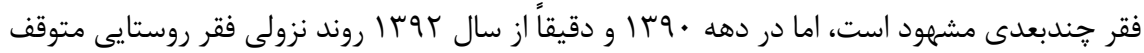
مىشود و كاهش معنادارى در آن ديده نمىشود و حتى در سال Vوسا افزايش جدى مى يابد (در جامعه شهرى بيش از دو برابر). r. روند كاهش سرشمار فقر در جامعه روستايى جدى تر و اميدوار كنندهتر است. همانطور كه مشاهده

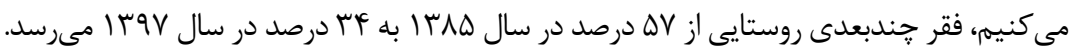
r. تفاوت ميزان شاخص فقر جندبعدى بين جامعه شهرى و روستايى بالاست. در شرايطى كه در

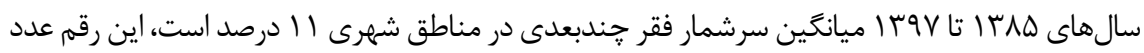

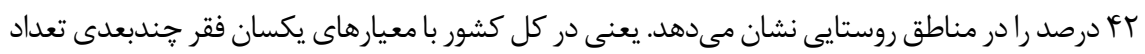

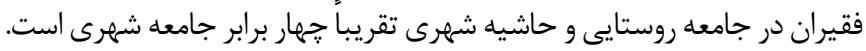

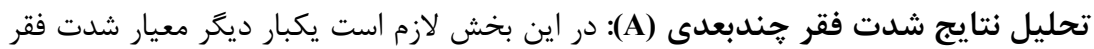

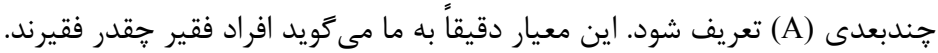

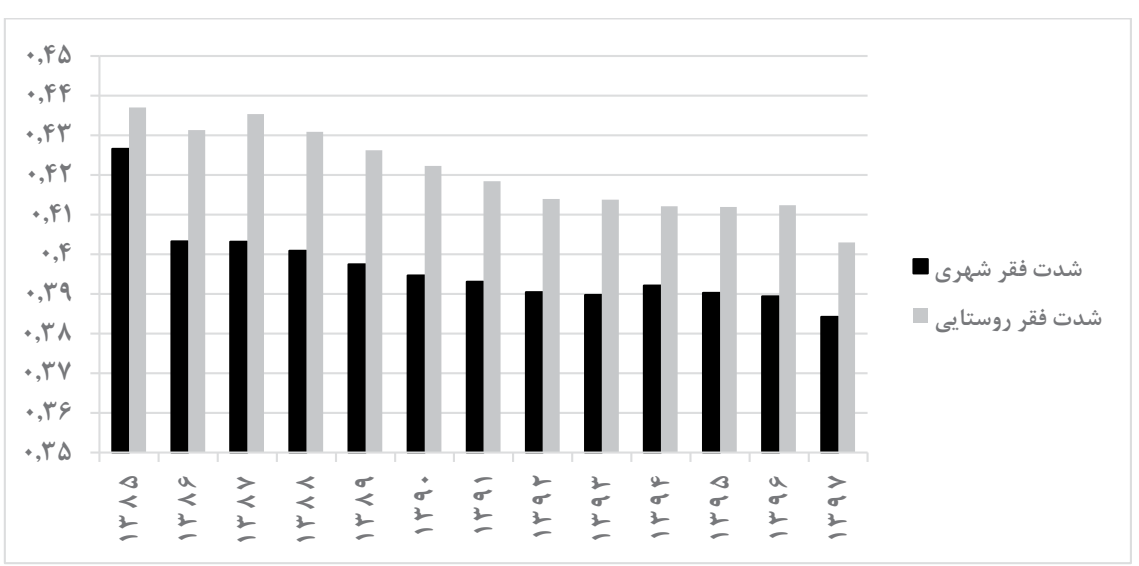

شكل r: روند شدت فقر جندبعدى در جامعه شهرى و روستايى

ا. سطح شدت فقر در ايران نسبت به ديگر كشورهاى درحالتوسعه جندان بالا نيست، زيرا بنابر

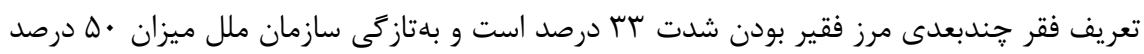


را براى فقر بسيار شديد معرفى مى كند. همانطور كه در شكل (r) مشاهده مىشود، براى ايران در

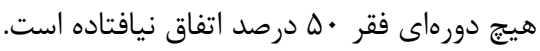

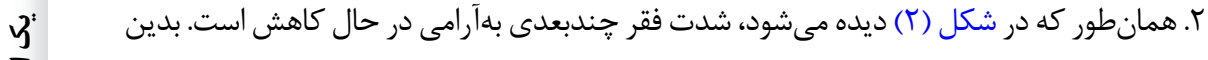
معنا كه تعداد افراد بسيار فقير يعنى كسانى كه در ابعاد متعدد داراى فقر هستند، در حال كاهش ملايم

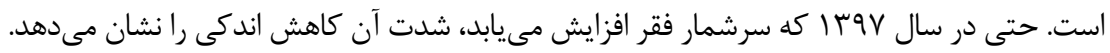
r. تفاوت شدت فقر جندبعدى براى جامعه شهرى و روستايى باز هم ديده مىشود كه البته به اندازه

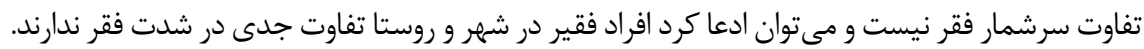

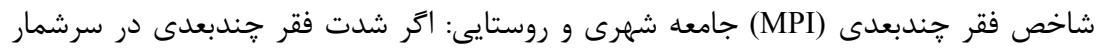

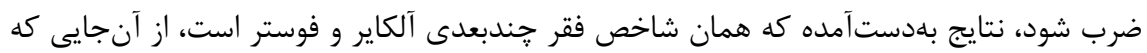

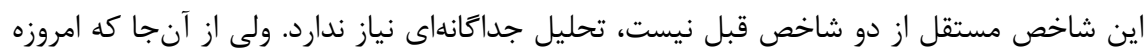
بلهور كامل در بانك دادهاى جهانى به عنوان يك شاخص توسعه گزارش مىشود، مىتواند براى

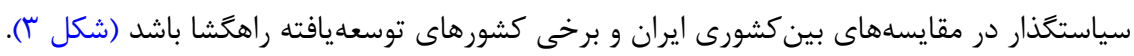

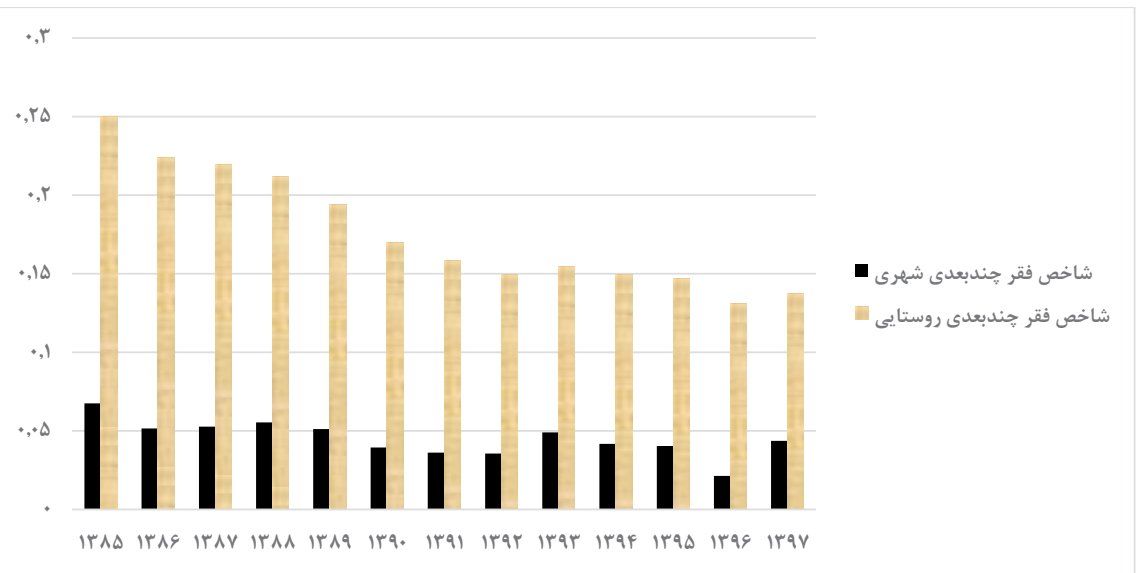
شكل "ّ: روند شاخص فقر جندبعدى براى جامعه شهرى و روستايى ايران

جغرافياى فقر جندبعدى در ايران: در اين بخش به مقايسه مناطق جغرافيايى ايران بر اساس

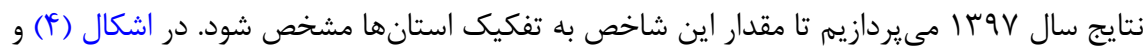
(ه)، سرشمار فقر جندبعدى براى جامعه شهرى و روستايى در سطح استانها به نمايش در آمده است. 


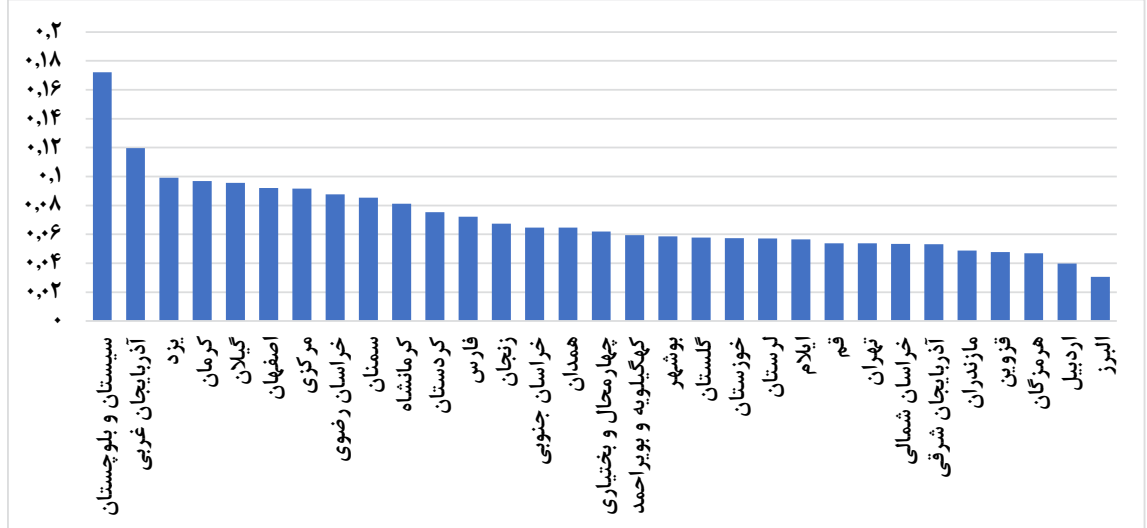

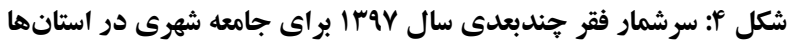

نتايج تفكيكى استانها براى مناطق شهرى نشان مىدهد كه حدود V درصد ساكنان شهرها در

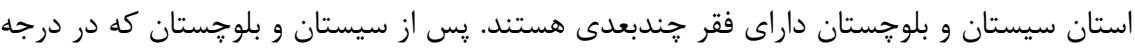
بالاى فقر قرار دارند، شهرهاى آذربايجان غربى با rا درصد، و يزد و كرمان هر يك با اندكى كمتر از • ا درصد قرار دارند. نكته عجيب و غيرقابل انتظار اين است كه همانطور كه از ميانههاى شكل (F) مشخص است، بيشتر شهرهاى بزرى مانند اصفهان، مشهل، شيراز، و حتى تهران فقر جندبعدى

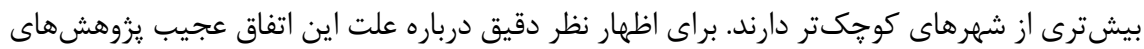
بيشترى نياز است، اما يك سناريو مىتواند گسترش زياد حاشيهنشينى در شهرهاى بزرى برى باشد.

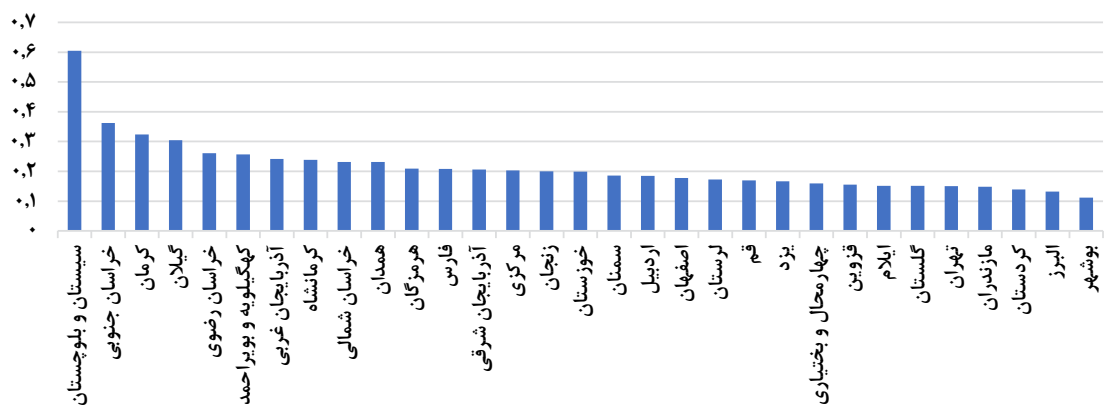

شكل ه: فقر جندبعدى سال YqT| براى جامعه روستايع در استانها 
نتايج تفكيكى استانها براى مناطق روستايى نشان مىدهد كه حدود •9 درصد ساكنان روستاها

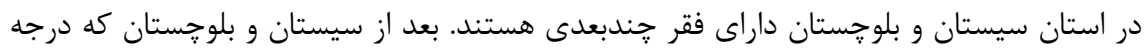

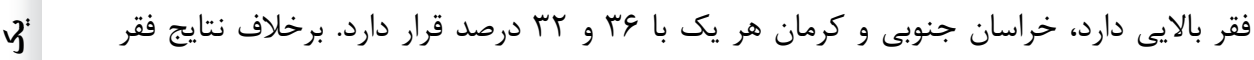
קندبعدى شهرى، در مناطق روستايى نتايج جندان تعجبآور نيست، و همانطور كه مشاهده مئشود، استانهاى سيستان و بلوجستان، خراسان جنوبى، و كرمان بهترتيب سه استان فقيرتر در مناطق

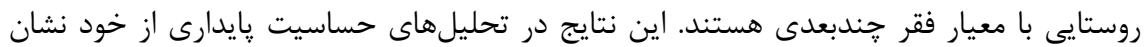

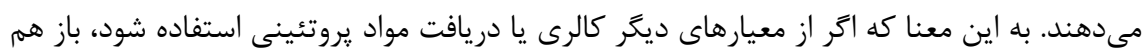

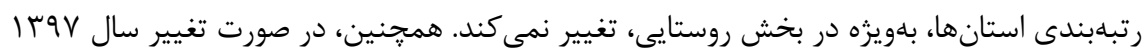

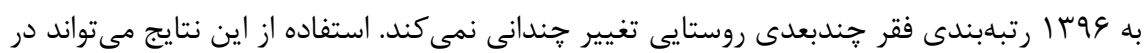

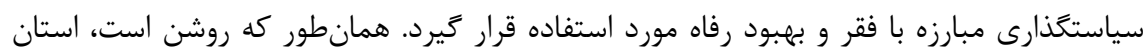
سيستان و بلوجستان، در هر دو فقر روستايى و شهرى، فقيرترين استان كشور است.

\section{بحث و نتيجه گيرى}

هدف اين يزوهش ارزيابى دقيقتر فقر به تفكيك استانى است، زيرا برخى گزارشها از جمله

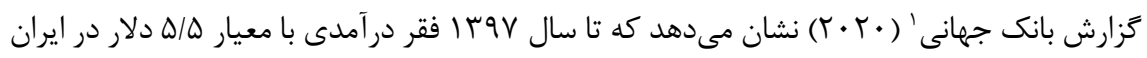
كاهشى نيست. اين يزوهش با استفاده از دادهاى هزينه در آمد خانوار نشان مى دهد كه فقر خهند

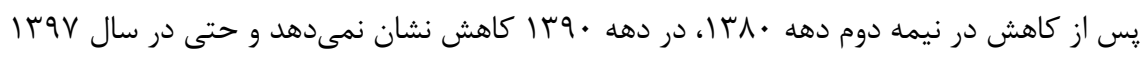

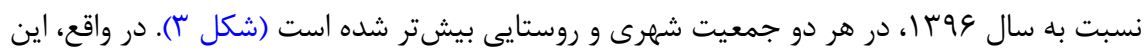

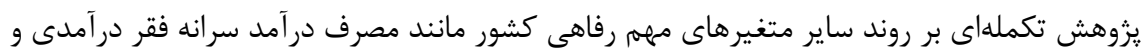

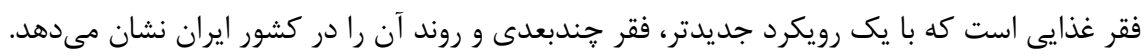
همجنين، در اين يزوهش تفكيك استانى براى شناسايى دقيقتر فقرا انجام مىشود، زيرا

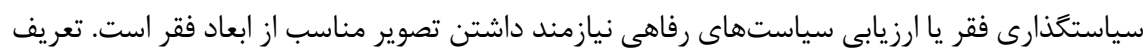

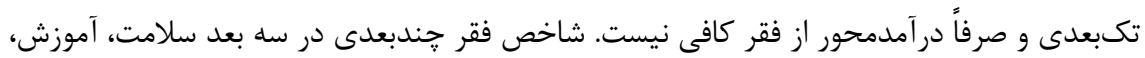
و استاندارد زندگى به محاسبه فقر مىيردازد و تصوير جامعترى براى سياستگذارى تهيه مىنمايد.

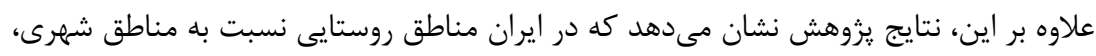

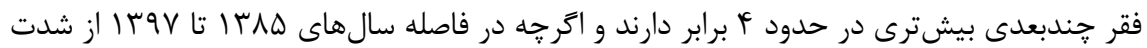


فقر كاسته مىشود شكل (Y)، اما سرشمار فقر يا همان تعداد فقيران در دهه • وبا و بهويزه از سال

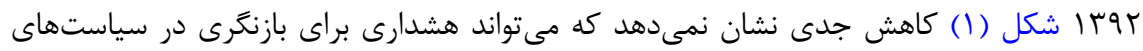
كاهش فقر در كشور ايران باشد.

با توجه به افزايش قيمت سوخت در سال دهو | و همجنين افزايش فشارهاى اقتصادى ناشى از تحريمها و بيمارى كرونا، توصيه مىشود يك يايحاه اطلاعاتى ايجاد و يويايىهاى فقر جندبعدى در كشور مدام رصد و ززارش شود.

\section{الف) فارسى}

منابع

خدادادكاشى، فرهاد، و حيدرى، خليل (1) (1). اندازمَيرى شاخصهاى فقر بر اساس عملكرد تغذيهاى

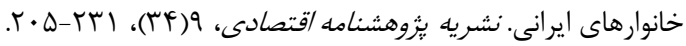

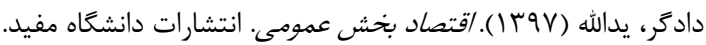

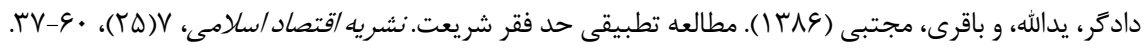

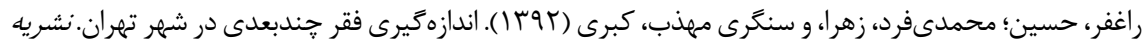

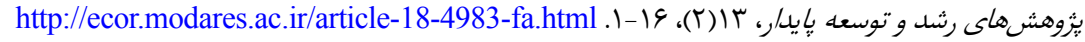

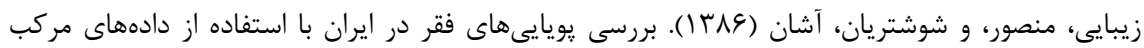

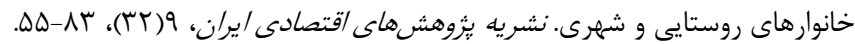

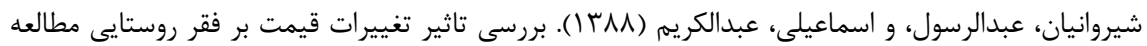

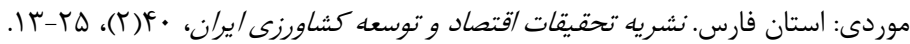

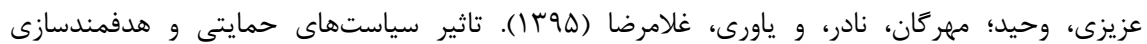

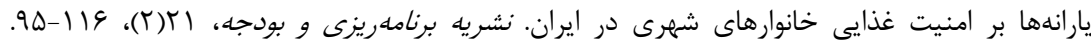
http://jpbud.ir/article-1-1235-fa.html

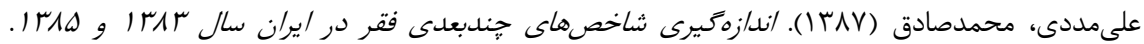

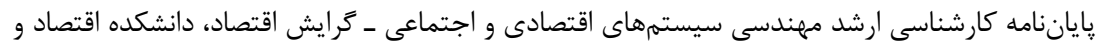
مديريت، دانشخاه صنعتى شريف.

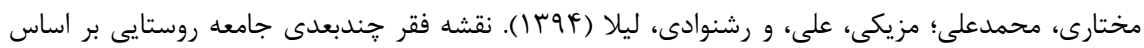

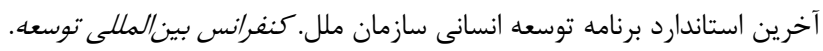




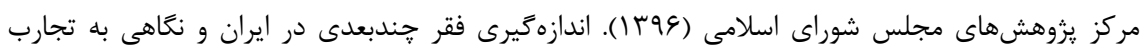

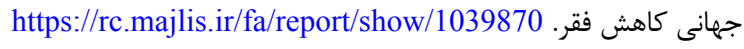

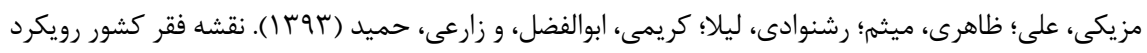

$$
\begin{aligned}
& \text { نيازهاى اساسى. كنفر/نس /قتصاد /يران. }
\end{aligned}
$$

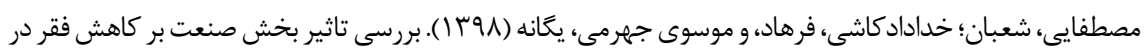

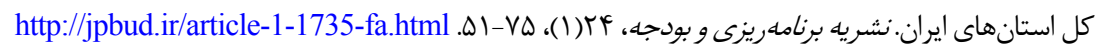

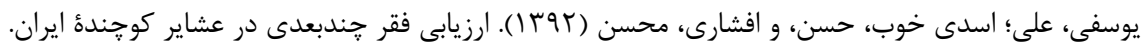

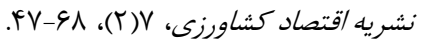

Alkire, S., \& Foster, J. (2011). Counting and Multidimensional Poverty Measurement. Journal of Public Economics, 95(7-8), 476-487. https://doi.org/10.1016/j.jpubeco.2010.11.006

Alkire, S., \& Jahan, S. (2018). The New Global MPI 2018: Aligning with the Sustainable Development Goals. Oxford Poverty \& Human Development Initiative (OPHI), Working Paper, No. 121

Batana, Y. (2008). Multidimensional Measurement of Poverty in Sub-Saharan Africa. Oxford Poverty \& Human Development Initiative (OPHI), Working Paper, No. 13.

Castro, J. F., Baca, J., \& Ocampo, J. P. (2012). Counting the Poor in Peru: A Multidimensional Approach. Latin American Journal of Economics, 49(1), 37-65.

Dhongde, S., \& Haveman, R. (2017). Multi-Dimensional Deprivation in the US. Social Indicators Research, 133(2), 477-500. https://doi.org/10.1007/s11205-016-1379-1

Karimi, S. M., Little, B. B., \& Mokhtari, M. (2020). Short-Term Fetal Nutritional Stress and Long-Term Health: Child Height. American Journal of Human Biology. https://doi.org/10.1002/ajhb.23531

Mazarei, A., \& Mirzoev, T. (2015). Four after the SPRING. Finance \& Development, 52(2), 55-57.

Sen, A. (1976). The Measurement of Poverty: An Axiomatic Approach. Econometrica, 44(1), 219-232.

Sen, A. (1981). Issues in the Measurement of Poverty. In Measurement in Public Choice (pp. 144-166): Springer.

World Bank. (2018). The World Bank Iran Economic Monitor. https://www.documents.worldbank.org 